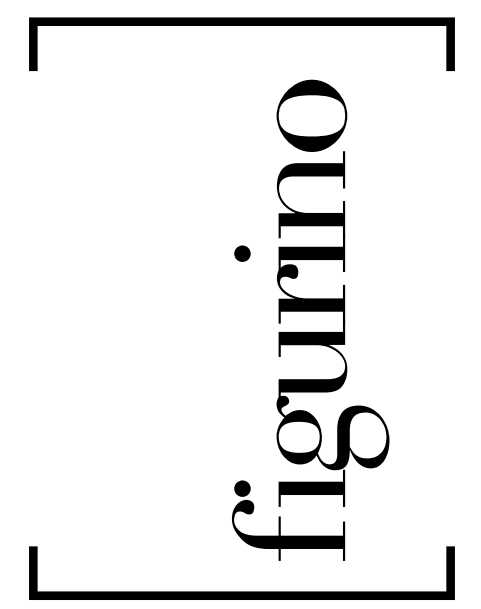

[ FAUSTO VIANA E ROSANE MUNIZ ]

Fausto Viana é figurinista, cenógrafo e pesquisador. Professor

livre-docente da Escola de Comunicação e Artes da Universidade

de São Paulo (ECA-USP). Coordenou o projeto de catalogação do

acervo de figurinos do Theatro Municipal de São Paulo. Participa

do projeto de pesquisa As tramas do café com leite. Colabora com

o blog www.vestindoacena.com

E-mail: faustoviana@uol.com.br

Rosane Muniz é jornalista, atriz e autora do livro Vestindo os nus: o figurino em cena (Senac Rio, 2004). Mestra em Artes Cênicas

(ECA-USP), mantém o blog www.vestindoacena.com

E-mail: romuniz@gmail.com

\title{
0 figurino teatral: a busca por unidade e raízes etnológicas
}

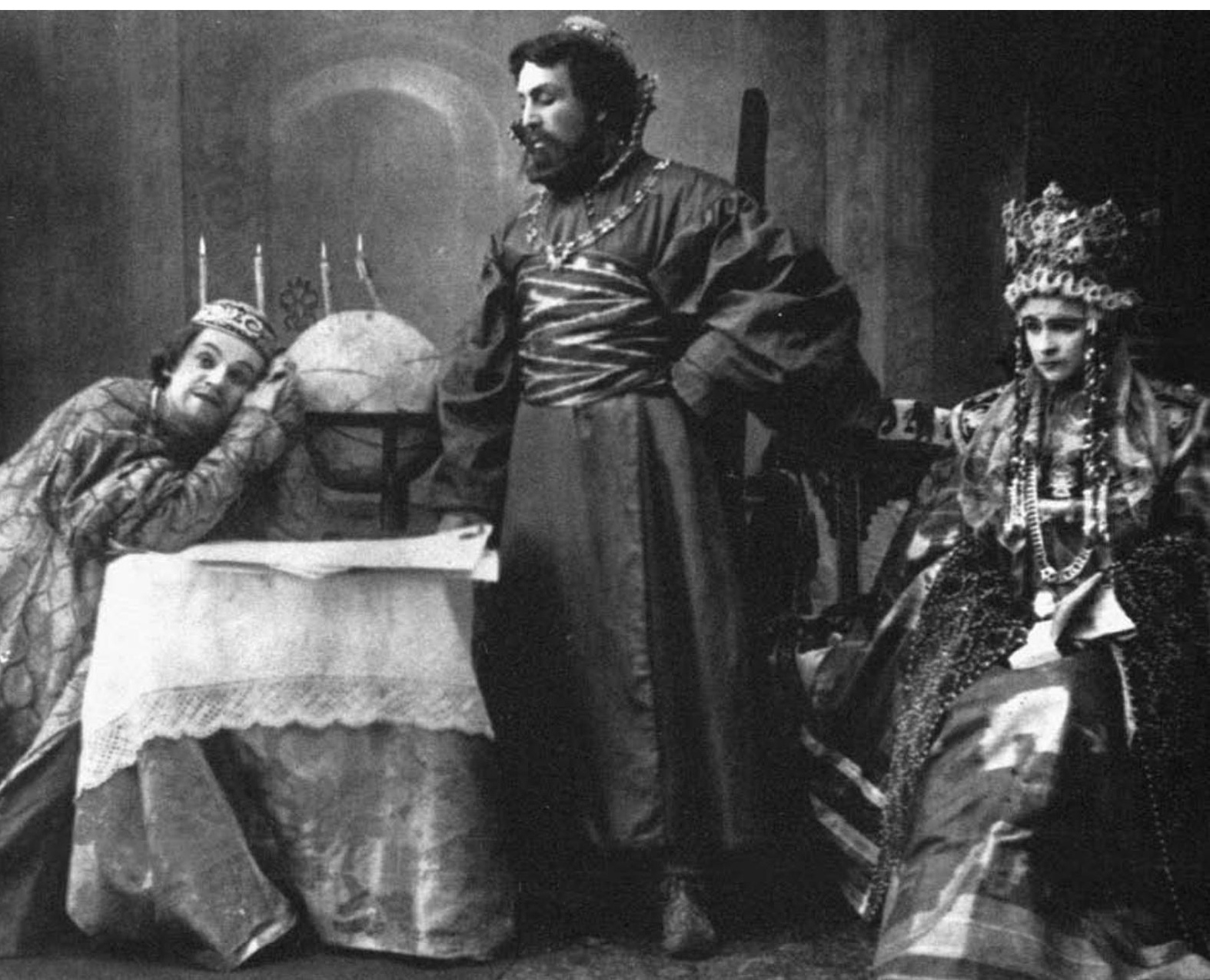

Cena do Ato III do espetáculo Tsar Fiódor Ivánovitch, direção de K. Stanislavski, encenado no Teatro de Arte de Moscou, em 1898.

Fonte: CHEVREL, Claudine Amiard. Le Théâtre Artistique de Moscou (1898-1917). Paris: Editions du CNRS, 1979, p. 188. 
Um exemplo recente é o de um casaco de lã de pescador, em Portugal, que sempre vimos em fotos e desenhos. Não sabíamos que ele havia sido impermeabilizado com azeite de oliva, porque era um casaco para ser usado na chuva e não poderia molhar. Quando, lá no Algarve, o responsável pelo museu contava as histórias - e toda a gente de teatro adora histórias! - ele falou que, uma vez, uma senhora muito velha tinha dito que o casaco era muito bom, funcionava mesmo, mas fedia muito! $E$ aí chegamos perto e o cheiramos, de leve, e a brisa não deixou dúvida. 0 odor do casaco, sem uso há mais de trinta anos, era uma mistura de bola de gordura com vela de sebo. E se você não consegue lembrar desse cheiro é porque provavelmente nunca precisou desse material ou viveu em algum lugar em que ele fosse necessário.

0 traje hoje pode até ser belo e usado somente por isso, mas na sua raiz sempre há um princípio de utilidade. Ele serviu para alguma coisa. Um exemplo é o que vimos no museu do teatro do Christiansborg Castle, em Copenhague. Apesar de conservado em situação razoável, o figurino usado pela atriz Betty Hennings para interpretar a personagem Nora, na première da peça Casa de Bonecas, de lbsen, em 1879, está se desfazendo. Mas o importante nesse contato não é só uma constatação de sua situação atual, e sim a possibilidade de observar a textura da indumentária, a delicadeza do tecido da saia e da pintura à mão, os detalhes das tramas da blusa... enfim, perceber que a beleza do traje original de tarantela que Nora usa mostra a obediência dessa mulher que, no realismo crítico do texto de lbsen, acabará por se transformar em uma clemência pela liberdade.

0 fascínio que um traje exerce no pesquisador ao poder tocá-lo - de luvas, é claro! - deve nos remeter ao seu histórico, mas, deixando a emoção de lado, é necessário aprofundar a pesquisa e entender o motivo de cada escolha para que se entenda também a história não só do traje, mas do teatro. E, por que não ousar dizer, para compreender melhor a história do nosso mundo?

\section{Em busca de sensações}

Assim, é preciso investigar, usar os sentidos, cheirar, tocar, olhar. Por que não, ouvir? E não é "conversa mediúnica" com roupa, não... muitos trajes têm sinos, metais, argolas, guizos, conchas, chifres, cuja sonoridade se encaixa em algum ritual.

0 traje naturalmente está envolvido quando se discutem os rituais e a etnologia. Ora, o que é que vestem os tais grupos étnicos? E o teatro não é mais uma das manifestações desses grupos?

Claro que sempre temos que ter bom senso. Mais uma vez retomamos Stanislavski para lembrar que durante os ensaios de Ralé, de Gorki, o grupo foi atrás dos mendigos a fim de tentar comprar seus trajes e usá-los na encenação. Ultimamente, algumas dessas criaturas que vivem nas ruas, não necessariamente mendigos, passam por nós e seu cheiro é desesperadoramente forte, algo que se sente a mais de três metros, um misto de urina, suor, chulé e fezes (quem foi mesmo que disse que o ser humano é um amontoado de carne e ossos, cheio de buracos que, se não lavar, fede?). Pronto, sentiu? Essa sensação já é suficiente como princípio criativo, tanto para o ator como para o figurinista.

Foi diante da sarna e das pulgas que Stanislavski mandou fazer reproduções das roupas. E o grupo experimentou a sensação, com certeza. Toda vivência física faz diferença: afinal, tudo o que passa pelo corpo não se esquece. 